\title{
META-ANALYSIS THE EFFECT OF PELVIC FLOOR MUSCLE TRAINING IN REDUCING URINARY INCONTINENCE IN WOMEN
}

\author{
Ragil Aidil Fitriasari Addini'), Eti Poncorini Pamungkasari²), \\ Bhisma Murti1) \\ ${ }^{1)}$ Masters Program in Public Health, Universitas Sebelas Maret \\ ${ }^{2)}$ Faculty of Medicine, Universitas Sebelas Maret
}

\begin{abstract}
Background: Urinary incontinence has a devastating effect on women's quality of life in the physical, social, sexual and psychological spheres. Pelvic floor muscle training is commonly recommended for both preventing and treating urinary incontinence. The purpose of this study was to examine the effect of pelvic floor muscle training in reducing urinary incontinence in women.

Subjects and Method: A systematic review and meta analysis was conducted by collecting articles from PubMed, Science Direct, and Google Schoolar databases. The determination of selected articles based on eligible criteria using PICO: (1) Population= female aged 20-75 years, (2) Intervention= pelvic floor muscle training, (3) Comparison= non pelvic floor muscle training, and (4) Outcome= urine incontinence. Keywords ("pelvic floor muscle training" OR "pelvic floor exercise" OR "kegel") AND ("urinary incontinence" OR "leaking urine" OR "urinary leakage") AND ("women" OR "female") AND "randomized controlled trial". The inclusion criteria were full text, randomized controlled trial study, published from 2010 to 2020. The articles were collected by PRISMA flow diagram. The selected articles were quantitatively examined by Review Manager $5 \cdot 3$

Results: Meta-analysis from 7 articles showed that pelvic floor muscle training reduced urine incontinence 0.56 times than other intervention or without any intervention $(\mathrm{SMD}=-0.56 ; 95 \% \mathrm{CI}=-1.03$ to $-0.09 ; \mathrm{p}=0.020)$.
\end{abstract}

Conclusion: Pelvic floor muscle training reduces urine incontinence in women.

Keywords: pelvic floor muscle training, urine incontinence

\section{Correspondence:}

Ragil Aidil Fitriasari Addini. Masters Program in Public Health, Universitas Sebelas Maret. Jl. Ir. Sutami 36A, Surakarta 57126, Central Java. Email: ragilaidilfa@gmail.com. Mobile: 089609133808. 